\title{
Probiotics as modulators of the gut flora
}

\author{
L. J. Fooks and G. R. Gibson* \\ Food Microbial Sciences Unit, School of Food Biosciences, The University of Reading, Whiteknights, \\ Reading RG6 6AP, UK
}

\begin{abstract}
Probiotic ingestion can be recommended as a preventative approach to maintaining the balance of the intestinal microflora and thereby enhance 'well-being'. Research into the use of probiotic intervention in specific illnesses and disorders has identified certain patient populations that may benefit from the approach. Undoubtedly, probiotics will vary in their efficacy and it may not be the case that the same results occur with all species. Those that prove most efficient will likely be strains that are robust enough to survive the harsh physico-chemical conditions present in the gastrointestinal tract. This includes gastric acid, bile secretions and competition with the resident microflora. A survey of the literature indicates positive results in over fifty human trials, with prevention/treatment of infections the most frequently reported output. In theory, increased levels of probiotics may induce a 'barrier' influence against common pathogens. Mechanisms of effect are likely to include the excretion of acids (lactate, acetate), competition for nutrients and gut receptor sites, immunomodulation and the formation of specific antimicrobial agents. As such, persons susceptible to diarrhoeal infections may benefit greatly from probiotic intake. On a more chronic basis, it has been suggested that some probiotics can help maintain remission in the inflammatory conditions, ulcerative colitis and pouchitis. They have also been suggested to repress enzymes responsible for genotoxin formation. Moreover, studies have suggested that probiotics are as effective as anti-spasmodic drugs in the alleviation of irritable bowel syndrome. The approach of modulating the gut flora for improved health has much relevance for the management of those with acute and chronic gut disorders. Other target groups could include those susceptible to nosocomial infections, as well as the elderly, who have an altered microflora, with a decreased number of beneficial microbial species. For the future, it is imperative that mechanistic interactions involved in probiotic supplementation be identified. Moreover, the survival issues associated with their establishment in the competitive gut ecosytem should be addressed. Here, the use of prebiotics in association with useful probiotics may be a worthwhile approach. A prebiotic is a dietary carbohydrate selectively metabolised by probiotics. Combinations of probiotics and prebiotics are known as synbiotics.
\end{abstract}

\section{Probiotics: Gut flora}

\section{Introduction}

Bacterial populations inside the gastrointestinal tract have adapted such that numbers of each genera are fairly consistent, having their own individual growth niche. In order for the intestine to function optimally however, the 'balance' of the bacterial flora must be maintained, and this appears to be increasingly difficult as lifestyles have changed. An increase in stress and modern day living, which makes a consequential demand on the immune system, can disrupt homeostasis in the gut. Similarly, the direct effects of a change in dietary patterns and eating habits can affect overall gut functionality. Another contributory factor includes the consumption of pharmaceutical compounds, in particular antibiotics, which by design destroy bacteria, and therefore can have a harmful effect on the balance of the gut microbiota. All of these combine to shift the balance of the gut microflora away from potentially beneficial or health-promoting bacteria such as the lactobacilli and bifidobacteria, towards an increase in harmful or pathogenic micro-organisms, like the clostridia, sulphate-reducers and proteolytic Bacteroides species. Predominance of the latter may pre-dispose towards a number of clinical disorders, including bowel cancer and inflammatory bowel diseases such as ulcerative colitis, whilst making the host more susceptible to infections by

\footnotetext{
Abbreviations: AAD, antibiotic-associated diarrhoea; FOS, fructo-oligosaccharides; GOS, gluco-oligosaccharides; SCFA, short-chain fatty acids; TOS, transgalacto-oligosaccharides.

* Corresponding author: Dr G. R. Gibson, fax +44 1189 357222, email g.r.gibson@ reading.ac.uk
} 
transient enteropathogens such as Salmonella, Campylobacter, certain species of Escherichia coli and Listeria. It is of considerable benefit to the host, therefore, to maintain a good community structure, through increased levels of bacteria such as lactobacilli and bifidobacteria, preferably at the expense of more harmful organisms. This gives justification to the use of probiotics as a way forward for the prophylactic treatment of enteropathogenic infections, as well as contributing towards protection against various intestinal diseases and disorders - especially those mediated by individual pathogens. What remains to be established is the extent to which probiotic organisms can be beneficial, to determine how any benefits may be manifest and to recognise any limitations.

\section{Definition of a probiotic}

Early attempts to classify probiotics were not generally accepted (Lilley \& Stillwell, 1965; Sperti, 1971). Parker (1974) proposed one early definition as organisms and substances that influence intestinal microbial balance. This definition was subsequently modified when Fuller (1989) redefined probiotics by removing the reference to 'substances', like microbial stimulants — which later became known as prebiotics (Gibson \& Roberfroid, 1995). Fuller's revised definition was: 'A live microbial feed supplement which beneficially affects the host animal by improving its intestinal microbial balance.' This modified version stressed the need for the supplement to be composed of viable micro-organisms. A recent formal definition of probiotics was agreed by a working party of European scientists and is given as 'a live microbial feed supplement that is beneficial to health' (Salminen et al. 1998). This emphasised the importance of definitive improvements in health.

A probiotic effect can therefore be manifest via the gut microflora by ingestion of viable micro-organisms, either in the form of specific preparations such as powders, tablets or capsules, or through yoghurts and other fermented foods. They can contain only one, or several different species of micro-organism.

\section{Development of the probiotic concept}

The large bowel harbours a nutritionally and physiologically diverse range of bacteria. This microflora offers the host protection against disease, and promotes normal intestinal function (Salminen et al. 1998). If the gastrointestinal flora becomes disrupted due to pathogens (Bartlett et al. 1987; Gorbach et al. 1987), dietary antigens (Salminen et al. 1998) or other harmful substances (Borgia et al. 1982; Colombel et al. 1987; Siitonen et al. 1990), this can lead to dysfunction of the intestine, and subsequently a number of disease states. Certain bacterial genera, namely Lactobacillus and Bifidobacterium, which have a long and safe history in the manufacture of dairy products, are therefore traditionally included in probiotic products to protect against such effects (Vaughan \& Mollet, 1999).

The first significant introduction of the probiotic concept was by Metchnikoff at the beginning of the 1900s. He believed that the complex microbial population in the colon was adversely affecting the host through so-called
Table 1. Examples of microbial species used as probiotics

Lactobacilli: e.g. L. acidophilus, L. casei, L. rhamnosus, L. reuteri, L. plantarum

Bifidobacteria: e.g. B. longum, B. bifidum, B. breve, B. infantis

Gram-positive cocci: e.g. Lactococcus lactis, Enterococcus faecium Yeast: e.g. Saccharomyces cerevisiae, Saccharomyces boulardii Fungi: e.g. Aspergillus orizae

'autointoxication', and reported that Bulgarian peasants, who consumed large quantities of fermented milk, experienced longevity (Metchnikoff, 1907). This was attributed to the health-promoting values of the live organisms. He therefore abandoned his practice of surgical removal of the colon, and began modification of the activity of the colonic microflora by the ingestion of soured milks. A Gram-positive rod, which he called the Bulgarian bacillus and later Bacillus bulgaricus, is likely to be the organism later known as Lactobacillus bulgaricus. This is now called L. delbrueckii subsp. bulgaricus, which together with Streptococcus salivarius subsp. thermophilus is responsible for the fermentation of milk to form traditional yoghurt.

Subsequent research looked to confirm that the consumption of lactic acid bacteria was having a beneficial effect on health. For example, preparations containing Lactobacillus acidophilus were used to alleviate constipation (Rettger et al. 1935), whilst concomitantly, in Japan, Shirota selected beneficial strains of lactic acid bacteria which could survive passage through the intestine, and subsequently used them to develop fermented milk drinks (Shortt, 1999). It was soon established that there were many species of lactic acid bacteria in the intestine, and these have subsequently been incorporated into many probiotic preparations. Table 1 shows lactic acid bacteria and other micro-organisms which are currently being used as probiotics either singly or in combination. Lactobacilli and bifidobacteria are the most frequently used genera.

Lactobacilli are Gram-positive, non-spore forming rods, catalase negative, usually non-motile and do not reduce nitrate. As glucose fermenters, they can be divided into biochemical subgroups on the basis of the metabolic route by which glucose is metabolised, either homofermentative or heterofermentative. According to $16 \mathrm{~S}$ rRNA sequencing data, lactobacilli may further be divided into three distinct 16S rRNA groups (Collins et al. 1991). The Lactobacillus population of the human gastrointestinal system consists of various species, subspecies and biotypes of the genera, with the most frequently isolated lactobacilli belonging to six species, L. acidophilus, L. salivarius, L. casei, L. plantarum, L. fermentum and L. brevis (Mikelsaar et al. 1998). Lactobacilli have GRAS (Generally Regarded As Safe) status (Salminen et al. 1998).

Bifidobacteria have also accumulated a high research profile as probiotic bacteria, largely due to their proposed health benefits. Species belonging to this genus were first isolated from the faeces of breast-fed infants by Tissier (1906). In the past, early strains of bifidobacteria had been variously assigned several taxonomic genera including Bacillus, Bacteroides, Tissieria, Nocardia, Lactobacillus, 
Actinomyces, Bacterium and Corynebacterium (Mitsuoka, 1984). However, bifidobacteria were classified into a separate genus (Rogosa, 1974) on the basis of their characteristic morphology, biochemistry, cell-wall constituents and DNA base composition (Scardovi et al. 1971). Bifidobacteria are Gram-positive, non-spore forming rods, with distinct cellular bifurcating or club-shaped morphologies. Since bifidobacteria constitute up to $25 \%$ of the gut microflora in some adult individuals, they make a significant contribution to carbohydrate fermentation in the colon. Hexoses are fermented by the fructose-6-phosphate, or 'bifidus' shunt (de Vries \& Stouthammer, 1968), which is characterised by the presence of the key enzyme fructose-6-phosphate phosphoketolase.

Ecological studies have demonstrated that bifidobacteria can be isolated from various microbial systems (Modler, 1994). For example, they are resident in the colons of humans and animals, and can also be found in the bodies of insects. Of the twenty-four species of Bifidobacterium so far recognised, nine are isolated predominantly from humans, B. bifidum, B. longum, B. infantis, B. breve, $B$. adolescentis, B. angulatum, B. catenulatum, B. dentium and B. pseudocatenulatum (Ballongue, 1998). The most common species found in the infant gut are $B$. infantis, $B$. breve, and $B$. longum, whilst $B$. adolescentis and $B$. longum are thought to predominate within the adult colon (Modler et al. 1990).

Newborn infants are firstly colonised with lactobacilli and bifidobacteria primarily via the birth canal during delivery, a hypothesis supported by evidence that infants born via the genital tract are colonised more rapidly than those delivered through caesarean section (Mitsuoka et al. 1974; Bezirtzoglou, 1985). The numerical differences in the lactobacilli and bifidobacterial populations between breast-fed and bottle-fed infants is significant. In healthy breast-fed infants, lactobacilli may account for up to $10^{7}$ per gram of faeces, with bifidobacterial levels at up to $10^{11}$ per gram, which are generally much higher than those of enterobacteria, and bacteroides within the first week of life (Mitsuoka, 1982; Yuhara et al. 1983; Benno et al. 1984). In contrast, in bottle-fed infants, lactobacilli numbers are only up to $10^{6}$ per gram faeces, with the bifidobacterial population at around $10^{10}$ per gram, this is coupled with increased numbers of enterobacteriacae, streptococci, bacteroides, E. coli and clostridia (Yuhara et al. 1983).

Numbers of bifidobacteria fall significantly upon weaning, and this occurs concomitant with an increase in populations of bacteroides, clostridia, enterobacteria and eubacteria, streptococci and even lactobacilli, such that the colonic bacterial profile typically resembles the adult pattern. These populations usually remain more or less stable throughout the adult population, until a decrease in bifidobacterial numbers is accelerated in the elderly (Mitsuoka, 1984). It is recognised however that throughout adult life, the homeostatic state of the gut can be altered by the factors described earlier and this may predispose towards acute and chronic disorders. One line of thinking as a means of combating this problem is to administer probiotics, to re-establish (for example) lactobacilli and/or bifidobacterial populations, and thereby restore the balance of the microflora, avoiding possible further infection, or subsequent sequelae which can result from a disrupted gut flora.

\section{Probiotic effects}

The gastrointestinal microflora has been identified as being involved in a number of disease states. These can include lactose intolerance, chronic diseases such as Crohn's disease and ulcerative colitis, acute gastroenteritis, food hypersensitivity and allergies, and colon cancer (Gibson \& Roberfroid, 1999). Primarily, these are thought to result from an imbalance of the normal microbial balance of the large intestine. This has highlighted the importance of so-called 'microbial interference treatment', i.e. the use of probiotics, as a means of infection control.

\section{Intestinal infections}

A number of clinical studies have used probiotics as dietary supplements for the prevention and treatment of gastrointestinal infections. These include infantile diarrhoea, travellers' diarrhoea, antibiotic-associated diarrhoea (AAD) and foodborne pathogenic diarrhoea.

Infantile diarrhoea. Rotavirus is a very common cause of infantile diarrhoea, and is frequently characterised by increased intestinal permeability (Jalonen et al. 1991) and higher serum levels of $\beta$-lactoglobulin containing immune complexes. Several studies have highlighted the ability of different probiotics, including various lactobacilli and bifidobacteria, to reduce the duration of rotavirus and watery diarrhoea (Table 2).

Antibiotic-associated diarrhoea. Clostridium difficile is thought to be an aetiologic agent of pseudomembranous colitis, one of the most common causes of AAD. Infection is commonly associated with prior or concomitant antimicrobial therapy, which can disrupt the normal flora balance allowing $C$. difficile to establish and produce at least two types of toxins (Salminen et al. 1998). These form a pseudomembrane composed of fibrin, mucin and epithelial cells that may eventually occlude the bowel. Probiotic bacteria have been found to have beneficial effects on both the prevention and treatment of AAD (Table 2). Both $B$. longum and Lactobacillus rhamnosus GG have been shown to decrease the course of erythromycin-induced diarrhoea. Two trials have found that Saccharomyces boulardii treatment significantly reduced the incidence of AAD (Surawicz et al. 1989; McFarland et al. 1994, 1995).

Overgrowth of candida in the gut is also a frequent consequence of antibiotic therapy. Studies in hamsters have shown that the gut microflora is involved in suppression of Candida albicans (Kennedy \& Volt, 1985). In gnotobiotic mice, $S$. boulardii protected against colonisation of the gut by $C$. albicans (Ducluzeau \& Bensaada, 1982). One human trial in patients undergoing chemotherapy treatment for leukaemia showed that a milk preparation containing $L$. acidophilus and a Bifidobacterium sp. was effective in reducing the count of candida in faeces (Tomoda et al. 1983).

Travellers' diarrhoea. A common aetiologic agent in travellers' diarrhoea is enterotoxigenic E. coli. A number 
Table 2. Examples of microbial infections and the effects of probiotics

\begin{tabular}{|c|c|c|c|c|}
\hline Disorder & Subject & Probiotics & Effect & Reference \\
\hline \multirow[t]{4}{*}{ Infantile diarrhoea } & Human & Lactobacillus GG & Reduced duration of diarrhoea & $\begin{array}{l}\text { Isolauri et al. (1991)) } \\
\text { Isolauri et al. (1994) } \\
\text { Kaila et al. (1992) } \\
\text { Majaama et al. (1995) } \\
\text { Raza et al. (1995) } \\
\text { Pant et al. (1996) }\end{array}$ \\
\hline & Human & Lactobacillus reuteri & Reduced duration of diarrhoea & Shornikova et al. (1997) \\
\hline & Human & B. bifidum + S. thermophilus & Prevented rotavirus diarrhoea & Saavedra et al. (1994) \\
\hline & Human & B. breve & Prevented diarrhoea & Hotta et al. (1987) \\
\hline \multirow[t]{4}{*}{$\begin{array}{l}\text { Antibiotic-associated } \\
\text { diarrhoea }\end{array}$} & Human & B. longum & $\begin{array}{l}\text { Decreased course of erythromycin- } \\
\text { induced diarrhoea }\end{array}$ & Colombel et al. (1987) \\
\hline & Human & Lactobacillus GG & $\begin{array}{l}\text { Decreased course of erythromycin- } \\
\text { induced diarrhoea, and other } \\
\text { side-effects of erythromycin }\end{array}$ & Siitonen et al. (1990) \\
\hline & Human & Streptococcus faecium & $\begin{array}{l}\text { Decreased diarrhoea associated with } \\
\text { antitubercular drugs administered for } \\
\text { pulmonary TB }\end{array}$ & Borgia et al. (1982) \\
\hline & Human & S. boulardii & Reduced incidence of diarrhoea & $\begin{array}{l}\text { Surawicz et al. (1989) } \\
\text { McFarland et al. (1995) } \\
\text { Elmer et al. (1996) }\end{array}$ \\
\hline \multirow[t]{2}{*}{$\begin{array}{l}\text { Relapsing } \\
\text { C. difficile colitis }\end{array}$} & Human & Lactobacillus GG & Improves/terminates colitis & $\begin{array}{l}\text { Gorbach et al. (1987) } \\
\text { Bartlett et al. (1987) }\end{array}$ \\
\hline & Human & Lactobacillus GG & Eradicated associated diarrhoea & $\begin{array}{l}\text { Bennet et al. (1990) } \\
\text { Biller et al. (1995) }\end{array}$ \\
\hline \multirow[t]{2}{*}{ Travellers' diarrhoea } & Human & L. acidophilus + B. bifidum & $\begin{array}{l}\text { Decreased frequency, not duration of } \\
\text { diarrhoea }\end{array}$ & Black et al. (1989) \\
\hline & Human & Lactobacillus GG & Decreased incidence of diarrhoea & $\begin{array}{l}\text { Oksanen et al. (1990) } \\
\text { Hilton et al. (1996) }\end{array}$ \\
\hline \multirow[t]{4}{*}{$\begin{array}{l}\text { Foodborne pathogen } \\
\text { exclusion }\end{array}$} & $\begin{array}{l}\text { Male BALB/c } \\
\text { mice }\end{array}$ & L. casei Shirota & $\begin{array}{l}\text { Increased resistance to lethal infection } \\
\text { with Salmonella, E. coli and } \\
\text { L. monocytogenes }\end{array}$ & Nomoto et al. (1989) \\
\hline & Male rat & Yoghurt bacteria & $\begin{array}{l}\text { Increased resistance to salmonellosis } \\
\text { infection }\end{array}$ & $\begin{array}{l}\text { Hitchins et al. (1986) } \\
\text { Bovee-Oudenhoven et al. } \\
\quad(1996)\end{array}$ \\
\hline & In vitro & $\begin{array}{l}\text { L. acidophilus + } \\
\quad \text { Lactobacillus GG }\end{array}$ & Inhibited growth of Salmonella & Brassart et al. (1995) \\
\hline & Human & Lactobacillus GG & $\begin{array}{l}\text { Decreased shigellosis-associated } \\
\text { diarrhoea }\end{array}$ & Sepp et al. (1995) \\
\hline
\end{tabular}

of studies have assessed the potential of probiotics to prevent this form of diarrhoea, with varying results depending upon the species used, vehicle and dosage schedule (Black et al. 1989; Oksanen et al. 1990). Nevertheless, a number of probiotic bacteria have been reported to result in beneficial effects, including Lactobacillus GG and B. bifidum (Table 2).

Foodborne pathogen associated gastrointestinal infection. Disruption of the normal balance of the resident gastrointestinal microbiota can allow establishment and growth of transient enteropathogens like Salmonella, Campylobacter, E. coli, Listeria and Shigella spp. Studies using animal models have established the ability of certain probiotics to inhibit pathogen growth (Table 2).

\section{Helicobacter pylori associated gastritis}

Helicobacter pylori has been associated with various gastric complaints such as stomach carcinoma and gastritis (Clayton \& Mobley, 1997). Although the target organ of probiotic organisms is usually the large intestine, their oral ingestion dictates their passage through the stomach.
Probiotic strains should be resistant to both gastric acid and bile salts, and may persist in the stomach for longer than other bacteria. In vitro investigations have established the ability of L. acidophilus and L. casei subsp. rhamnosus to inhibit H. pylori (Brassart et al. 1995; Midolo et al. 1995; Lambert \& Hull, 1996), whilst lactic acid bacteria generally were found to produce anti-Helicobacter factors (Luo et al. 1994). An animal model using gnotobiotic mice found $L$. salivarius to be effective in inhibiting $H$. pylori (Kabir et al. 1997), whilst in a human trial, L. acidophilus was effective at inhibiting colonisation of the organism (Michetti et al. 1995). However, given the rapid transit time of organisms in the stomach and the physical location of $H$. pylori therein, it is debatable whether probiotics can exert any major effect against the pathogen.

\section{Immunomodulatory and immunostimulatory functions}

Some sections of the human population may have a dysfunctional immune response, e.g. infants, the elderly, surgical patients, trauma victims, the immunocompromised, and stressed individuals. Conventional immunostimulatory 
Table 3. Immunostimulatory effects of probiotics

\begin{tabular}{|c|c|c|c|c|}
\hline Disorder & Subject & Probiotics & Effect & Reference \\
\hline \multirow[t]{2}{*}{ Food allergy } & Rodent & Lactobacillus GG & $\begin{array}{l}\text { Highlighted the importance of the route of } \\
\text { antigen absorption in determining the } \\
\text { subsequent immune response to that antigen }\end{array}$ & Isolauri et al. (1993) \\
\hline & Human & Lactobacillus GG & $\begin{array}{l}\text { Modulated the immune response to dietary } \\
\text { antigen in milk-hypersensitive adults }\end{array}$ & Pelto et al. (1996) \\
\hline Atopic dermatitis & Human & Lactobacillus GG & $\begin{array}{l}\text { Degraded food antigens, leading to down- } \\
\text { regulation of T-cell responses. Possible release } \\
\text { of tolerogens from allergens }\end{array}$ & Sütas et al. (1996) \\
\hline
\end{tabular}

approaches have been either vaccines, which are not only ineffective in immunocompromised individuals but also incur high costs from widespread use, or immunostimulatory pharmaceuticals, which are generally effective but cause adverse effects such as fever, headache, vomiting and hypertension. In man, probiotic bacteria have been found to have immunostimulatory properties for the treatment of viral diarrhoea but also with application to food allergies/hypersensitivity and atopic dermatitis (Table 3) either of which can be attributed to, or associated with, an excess of dietary allergens. In a human trial, twentyfour subjects were fed $450 \mathrm{~g}$ of yoghurt daily for four months, and at the end of that period, T-lymphocytes isolated from the volunteers showed significant increase in the production of $\gamma$-interferon (Halpern et al. 1991).

\section{Mechanisms of probiotic activity}

The exact manner in which probiotics may achieve their effect(s) is still uncertain. However, some mechanisms can be speculated upon, such as chemical inhibition or stimulation, competition for nutrients, immune clearance and competition for adhesion receptors.

\section{Biochemical effects}

One mechanism by which organisms may inhibit one another is via the production of bacteriocins. These are proteins, or protein complexes, produced by certain strains of bacteria, which can have antagonistic action against species that are closely related to the producer bacterium (Meghrous et al. 1990). Gibson \& Wang (1994) suggested that some strains of bifidobacteria could inhibit a variety of pathogenic bacteria through a non-pH related effect. Furthermore, B. bifidum strain NCFB 1454 was found to excrete a bacteriocin which was antagonistic to potent enteropathogens and food-spoilage bacteria, such as Listeria, Enterococcus, Bacillus, Lactobacillus, Leuconstoc and Pediococcus spp. (Anand et al. 1984, 1985; Yildrim \& Johnson, 1998). Other bacterial species known to produce bacteriocins include lactobacilli and lactococci (Talarico \& Dobrogosz, 1989).

Short-chain fatty acids (SCFA) are also produced in varying quantities as metabolic end products by lactobacilli and bifidobacteria, and it is thought that these may induce an antagonistic effect against other organisms. Furthermore, the accumulation of such metabolites acts to reduce the $\mathrm{pH}$ of their surrounding environment, and it is likely that this may act directly to inhibit the growth of harmful and pathogenic organisms, by producing an undesirable environment.

Both lactobacilli and bifidobacteria are capable of preventing the adherence, establishment, replication, and/or pathogenic action of specific enteropathogens (Saavedra, 1995). A number of mechanisms by which these antagonist properties may be manifest have been proposed, such as decreasing the luminal $\mathrm{pH}$ via the production of SCFA, rendering specific nutrients unavailable to pathogens, and/or producing specific inhibitory compounds such as bacteriocins (Sanders, 1993).

Both lactobacilli and bifidobacteria are saccharolytic in their fermentation strategies. Lactobacilli are divided into biochemical subgroups on the basis of the metabolic route by which glucose is metabolised, either homofermentative or heterofermentative species. Homolactic fermentation involves splitting of hexoses into $\mathrm{C}_{3}$ moieties by fructose-1,6-bisphosphate via the glycolytic pathway, to yield two pyruvates, which are then converted to two lactates. Concomitant with this is the generation of $2 \mathrm{~mol}$ ATP/mol glucose. Heterolactic fermentation dissimilates hexoses via the pentose phosphate pathway to produce lactate, $\mathrm{CO}_{2}$ and ethanol, generating $1 \mathrm{~mol} \mathrm{ATP} / \mathrm{mol}$ glucose. The key enzyme in this pathway is phosphoketolase, which hydrolyses xylulose-5-phosphate to acetyl-CoA and glyceraldehyde-3-phosphate. In addition, pentoses are fermented via this pathway by heterofermentative lactic acid to equimolar amounts of lactate and acetate. Some homofermentative species possess inducible phosphoketolase and can thereby also ferment pentoses to equimolar amounts of lactate and acetate (Lindgren \& Dobrogosz, 1990).

Since bifidobacteria are a numerically significant bacterial population in the colonic microflora, they play a vital role in carbohydrate fermentation in the colon. Bifidobacteria ferment hexoses by the fructose-6-phosphate, or 'bifidus' shunt (de Vries \& Stouthammer, 1968), as characterised by the presence of the key enzyme fructose6-phosphate phosphoketolase. This enzyme cleaves fructose-6-phosphate into acetyl-1-phosphate and erythrose-4-phosphate, the latter of which is converted to pyruvate. The principal end products of fermentation are acetate and lactate, produced in a 3:2 ratio, as follows:

$$
\begin{aligned}
& 2 \text { Glucose }+5 \mathrm{ADP}+5 \mathrm{P}_{\mathrm{i}} \\
& \longrightarrow 3 \text { Acetate }+2 \text { Lactate }+5 \mathrm{ATP}
\end{aligned}
$$

Antimicrobial compounds produced by lactic acid 
bacteria, lactobacilli and bifidobacteria include fermentation products, such as organic acids, hydrogen peroxide, and diacetyl, but many lactic acid bacteria also produce antimicrobial peptides (De Vuyst \& Vandamme, 1994). These compounds have an important role in inhibiting the growth of spoilage organisms, and for this reason have attracted attention as potential fermented food preservatives (Ouwehand, 1998). Two groups of antimicrobial substances have been identified, low molecular weight antimicrobial substances, for example, reuterin, produced by $L$. reuteri; and bacteriocins (Ouwehand, 1998). The latter have been most thoroughly investigated, and are defined as biologically active proteins, or protein complexes, of high molecular weight, which act bactericidally against Gram-positive bacteria, usually closely related to the producer strain (Klaenhammer, 1988). Bacteriocins are divided into four classes: Class I - lantibiotics; Class II - small hydrophobic, heat-stable peptides $(<13 \mathrm{kDa})$; Class III - large heat-labile proteins $(>30 \mathrm{kDa})$; and Class IV - complex bacteriocins: proteins with lipid and/ or carbohydrate (Nes et al. 1996). Class I and Class II bacteriocins are currently the most widely studied (Jack et al. 1995; Nes et al. 1996; Sahl \& Bierbaum, 1998). Most of the bacteriocins of Lactobacillus spp. belong to the Class II bacteriocins. One Lactobacillus sp., L. plantarum, is most often associated with bacteriocin production. A number of bacteriocins have been isolated from various L. plantarum strains. The production of bacteriocins from bifidobacterial strains is less well documented, but two different B. bifidum strains were found to produce a bacteriocin (Kebary, 1995; Yildrim \& Johnson, 1998), whilst another commercial, bifidobacterial strain was reported to produce a bacteriocin (Meghrous et al. 1990). Bifidobacteria can also exert direct inhibitory effects against Gram-negative pathogens like campylobacters, salmonellae and E. coli (Gibson \& Wang, 1994).

\section{Competition for nutrients}

The ability to compete for limiting nutrients is an important factor that determines composition of the gut flora, with species that are unable to compete being effectively eliminated from the system. Bacteria in the large intestine are subject to a range of substrate availability; species in the proximal colon have a large supply of nutrients, provided by dietary residues transiting from the small intestine, whilst those occupying the distal region of the colon have more limited substrate availability. Increasing lactobacilli/bifidobacterial numbers by way of a probiotic may thereby decrease the substrate available for other bacterial populations.

\section{Immune clearance}

The potential of the immune response to control growth of micro-organisms in the gut is an important consideration. It has been suggested that surface immunoglobulin A attached to the mucosal membrane may limit or inhibit adherence of enteropathogens invading the gastrointestinal tract (Perdigon et al. 1990). Stimulation of systemic components of the immune system, in particular the cellmediated response, may help to regulate changes in the gut microflora, for example by increasing macrophage phagocytic activity using lactic acid bacteria (Hatcher \& Lambrecht, 1993).

\section{Attachment}

One possible mechanism for the action of probiotics is their ability to adhere to the intestinal mucosa (Jacobsen et al. 1999). In this way, they may resist peristalsis which would otherwise flush them from the gut. As well as occupying a niche at the expense of potentially harmful organisms, they may specifically block the adherence of enteropathogens. The $\mathrm{CaCo}-2$ cell line is a suitable model for investigating adherence mechanisms, in particular since such cells display typical features of enterocytic intestinal cells (Holzapfel et al. 1998). This cell line has been used in a number of studies, to demonstrate that $L$. acidophilus (Coconnier et al. 1993; Bernet et al. 1994) and L. casei (Hudault et al. 1997) adhere in relatively high numbers. This may be at the expense of enteropathogens such as Salmonella typhimurium, Yersinia enterolitica and enteropathogenic E. coli.

\section{Prebiotics}

Since the viability of live bacteria in food products and during transit through the gastrointestinal tract may be variable, the prebiotic concept has been developed. Here, the selective growth of certain indigenous gut bacteria is proposed. A prebiotic is a "non digestible food ingredient that beneficially affects the host by selectively stimulating the growth and/or activity of one or a limited number of bacteria in the colon, that can improve the host health' (Gibson \& Roberfroid, 1995). Thus, the prebiotic approach advocates the administration of non-viable entities and therefore overcomes any viability problems in the upper gastrointestinal tract. Certain oligosaccharides which cannot be digested, except through bacterial activity, are prebiotics. Those that contain fructose (e.g. inulin) can alter the composition of the human gut flora, by a specific fermentation, towards a community predominated by bifidobacteria (Gibson et al. 1995).

Criteria which allow the classification of a food ingredient as a prebiotic, include:

(1) It must be neither hydrolysed, nor absorbed in the upper part of the gastrointestinal tract.

(2) Selective fermentation by one or a limited number of potentially beneficial bacteria in the colon.

(3) Alteration of the composition of the colonic microbiota towards a healthier composition.

(4) Induction of effects which are beneficial to the host's health.

Any dietary ingredient that reaches the colon, e.g. nondigestible carbohydrates, some peptides and proteins, as well as certain lipids, is a candidate prebiotic. Non-digestible carbohydrates, like oligosaccharides, are the most likely prebiotics (Gibson et al. 2000). Fructo-oligosaccharides (FOS) are $\beta$-D-fructans with degrees of polymerisation varying between 2-60 (inulin) and 2-20 (oligofructose). They have several $\beta(1-2)$ - or $\beta(1-6)$-linked fructose 
residues, which may be linked to a glucose residue. A number of other non-digestible oligosaccharides have now been developed, for which there is evidence for their prebiotic effect. These include gluco-oligosaccharides (GOS), galacto-oligosaccharides, transgalacto-oligosaccharides (TOS), isomalto-oligosaccharides, xylo-oligosaccharides, and soyabean-oligosaccharides (Kohmoto et al. 1988; Hayakawa et al. 1990; Ito et al. 1990; 1993; Imaizumi et al. 1991; Saito et al. 1992; Roberfroid et al. 1999).

Of all the prebiotics tested, the inulin type fructans have been the most thoroughly investigated. The fermentability of various dietary components has been studied in vitro using mixed faecal culture, with the most predominant culturable bacterial groups, including bacteroides, clostridia, lactobacilli and bifidobacteria being enumerated (Wang \& Gibson, 1993). Bifidobacteria selectively fermented the inulin-type fructans, in preference to other carbohydrate sources such as starch, fructose, pectin and polydextrose. This was subsequently confirmed in a human trial, which examined the bifidogenic effect of FOS (Gibson et al. 1995). Human volunteers were fed a strictly controlled diet, which in the test group was supplemented with $15 \mathrm{~g} / \mathrm{d}$ of FOS. In comparison to the placebo group in which sucrose was administered, a bifidogenic effect was observed, with a significant increase in bifidobacterial numbers, concomitant with a decrease in the numbers of bacteroides, fusobacteria and clostridia. More recently, a study used a continuous culture system to examine the bifidobacterial ecology and FOS metabolism, and found that bifidobacterial numbers increased during $48 \mathrm{~h}$ fermentation (McBain \& Macfarlane, 1997). Such data have also been confirmed in other human studies (Buddington et al. 1996; Kleesen et al. 1997).

GOS have as yet not been so extensively investigated. Whilst the bifidogenic effect of this sugar has been reported (Ahn et al. 1997), another study which fed gnotobiotic rats a diet of $40 \mathrm{~g} / \mathrm{d}$ of GOS, found little effect on bacterial groups, although modification of numerous glycolytic activities was observed. In particular, $\beta$-galactosidase and $\alpha$-galactosidase were increased, whilst a decrease in levels of $\beta$-glucuronidase was observed (Djouzi \& Andrieux, 1997). Beta-galactosidase and $\alpha$-galactosidase have been reported to improve the fermentation of resistant starch and lactulose, leading to increased production of SCFA and lactate (Macfarlane \& Cummings, 1991). Furthermore, $\beta$-glucuronidase is involved in generation of toxic and carcinogenic metabolites in the distal colon, and therefore reduction of the activity of this enzyme could help to prevent development of cancer.

TOS are manufactured from lactose by transglycosylation reactions and consist of galactosyl derivatives of lactose with $\beta 1-3$ and $\beta 1-6$ linkages. Bifidobacterial numbers were significantly increased in the faeces of rats fed TOS (Djouzi \& Andrieux, 1997), confirming data from earlier experiments (Tanaka et al. 1983; Mitsuoka, 1990). One study used TOS in a human volunteer trial to determine their effect on faecal flora. In keeping with findings from other studies, bifidobacteria and Lactobacillus numbers were increased, whilst decreasing the numbers of Bacteroides spp. and Candida (Ito et al. 1993). The bifidogenic nature of TOS has been related to the linkage specificity of the Bifidobacterium $\beta$-galactosidase, which specifically cleaves $\beta 1-3$ and $\beta 1-6$ linkages, instead of $\beta 1-4$ linkages (Dumortier et al. 1994).

Isomalto-oligosaccharides such as isomaltose, panose and isomaltriose, have $\alpha 1-6$ glucosidic linkages. Their effects on the faecal flora have been examined, and were shown to be fermented by bifidobacteria and Bacteroides fragilis, but not by E. coli or other bacterial populations (Kohmoto et al. 1988). Other studies have examined the soyabean-oligosaccharides, raffinose and stachyose (Hayakawa et al. 1990). All bifidobacterial species tested fermented this carbohydrate source, with the exception of B. bifidum, whilst L. salivarius, Bact. fragilis and Mitsuokella multiacida metabolised the substrate, but to a lesser degree.

These results suggest that all of these oligosaccharides have the potential for being used for human ingestion, to enhance numbers of bifidobacteria, without increasing numbers of other bacterial populations which may otherwise have harmful effects on host health. Since there is evidence for their purported effects, prebiotics can therefore justifiably be used as dietary supplements to alter the gut flora composition.

Inhibition of growth of some human enteropathogens such as salmonellae has been reported in the presence of FOS (Oyarzabal \& Conner, 1995), whilst others report bifidobacterial antagonistic activity against Gram-negative species, such as Salmonella, Campylobacter and E. coli (Gibson \& Wang, 1994). Since both salmonellae and campylobacters are very common aetiological agents in gastroenteritis and diarrhoeal disease, there is clearly a market potential for the prophylactic or direct treatment of such infections.

\section{Synbiotics}

A further possibility in microflora management procedures is the use of synbiotics, whereby probiotics and prebiotics are used in combination (Gibson \& Roberfroid, 1995). The live microbial additions may be used in conjunction with a specific substrate for growth; for example, FOS with a Bifidobacterium strain. The end result should be improved survival of the probiotic, which has a readily available (and specific) substrate for its fermentation, as well as the individual advantages that each may offer.

The approach could have particular application in infants and the elderly. An accumulation of literature has reported the benefits of breast-feeding infants, as compared to bottle-feeding, in terms of the predominance of different bacterial groups (Bennet \& Nord, 1987; Benno et al. 1984; Baquero et al. 1988; Kay et al. 1990). Administration of a bifidobacteria and/or a bifidogenic prebiotic could increase numbers in the intestine. In individuals above the age of about 55-60 years, faecal bifidobacterial counts are thought to show a marked decrease (Mitsuoka, 1990; Kleesen et al. 1997, 2001). This may be relevant in the susceptibility of these individuals to pathogenic infection. As nearly half of the UK population is comprised of children and adults over the age of 60 , there is clearly a substantial target population for gut flora interactions. 


\section{Conclusions}

The area of gut flora modulation seems to hold much promise for the prophylactic management and/or treatment of gut disorders, as mediated by pathogens. For probiotics, many promising studies have been published. However, it is relevant to note that studies on particular strains may not necessarily be extrapolated to all probiotic microorganisms. Each should be assessed on their individual merits. Moreover, it is important that reliable labelling information on microbial contents and numbers are given. For prebiotics, the generation of forms that act at the species, rather than genus, level offers further refinement to the approach (Rabiu et al. 2001). Such speciesspecific oligosaccharides may be used in combination with proven probiotics to enhance their survival, i.e. as synbiotics.

\section{References}

Ahn J-B, Hwang J-K, Kim C-T, Lee K-H \& Park J-H (1997) Bifidogenic effect of gluco-oligosaccharide prepared from glucose by extrusion process. Journal of Microbiology and Biotechnology 7, 174-179.

Anand SK, Srinivasan RA \& Rao LK (1984) Antibacterial activity associated with Bifidobacterium bifidum. Cultured Dairy Production Journal Nov: 6-8.

Anand SK, Srinivasan RA \& Rao LK (1985) Antibacterial activity associated with Bifidobacterium bifidum - II. Cultured Dairy Production Journal, Feb: 21-23.

Ballongue J (1998) Bifidobacteria and probiotic action. In Lactic Acid Bacteria, Microbiology and Functional Aspects, 2nd ed., pp. 519-587 [S Salminen and A von Wright, editors]. New York: Marcel Dekker.

Baquero F, Fernandez-Jorge A, Vicente MF, Alos JI \& Reig M (1988) Diversity analysis of the human intestinal flora: a sample method based on bacterial morphotypes. Microbial Ecology in Health and Disease 1, 101.

Bartlett JG, Chang TW \& Gurwith M (1987) Antibiotic-associated pseudomembranous colitis due to toxin-producing clostridia. New England Journal of Medicine 57, 141-145.

Bennet RG, Laughon B \& Lindsay J (1990) Lactobacillus GG treatment of Clostridium difficile infection in nursing home patients. Abstract, 3rd International Conference on Nosocomial Infections. Atlanta.

Bennet R \& Nord CE (1987) Development of the faecal anaerobic microflora after caesarian section and treatment with antibiotics in newborn infants. Infection 15, 332.

Benno Y, Sawada K \& Mitsuoka T (1984) The intestinal microflora of infants: composition of faecal flora in breast-fed and bottle-fed infants. Microbiology and Immunology 28, 975.

Bernet MF, Brassart D, Neeser JR \& Servin AL (1994) Lactobacillus acidophilus La1 binds to cultured human intestinal cell lines and inhibits cell attachment and cell invasion by enterovirulent bacteria. Gut 35, 483-489.

Bezirtzoglou E (1985) Contribution à l'étude de l'implantation de la flore fécale anaérobie du nouveau-né mis au monde par césariene. Thèse, Paris-Sud.

Biller JA, Katz AJ, Flores AF, Buie TM \& Gorbach SL (1995) Treatment of recurrent Clostridium difficile colitis with Lactobacillus GG. Journal of Pediatric Gastroenterology and Nutrition 21, 224-226.
Black FT, Andersen PL, Ørskov F, Gaarslev K \& Laulund S (1989) Prophylactic efficacy of lactobacilli on traveller's diarrhoea. Travellers Medicine 8, 1750-1753.

Borgia M, Sepe N, Brancato V \& Borgia RA (1982) A controlled clinical study on Streptococcus faecium preparation for the prevention of side reactions during long-term antibiotic therapy. Current Therapeutic Research 31, 265-271.

Bovee-Oudenhoven I, Termont D, Dekker R \& van der Meer R (1996) Calcium in milk and fermentation by yoghurt bacteria increase the resistance of rats to Salmonella infection. Gut 38, 59-65.

Brassart D, Neeser J-R, Michetti P \& Sevin A (1995) The selection of dairy bacterial strains with probiotic properties based on their adhesion to human intestinal epithelial cells. In Les Bacteries Lactiques/Lactic Acid Bacteria, pp. 201-212. Adria Normandie: Presses Universitaires de Caen.

Buddington RK, Williams CH, Chen SC \& Witherly SA (1996) Dietary supplementation of neosugar alters the faecal flora and decreases activities of some reductive enzymes in human subjects. American Journal of Clinical Nutrition 63, 709-716.

Clayton CL \& Mobley HLT (1997) Helicobacter pylori Protocols. New Jersey: Humana Press.

Coconnier MH, Bernet MF, Kerneis S, Chauverie G, Fourniat J \& Servin AL (1993) Inhibition of adhesion of enteroinvasive pathogens to human intestinal Caco-2 cells by Lactobacillus acidophilus strain LB decreases bacterial invasion. FEMS Microbiology Letters 110, 299-305.

Collins MD, Rodrigues U, Ash C, Aguirre M, Farrow JAE, Martinez-Murcia A, Phillips BA, Williams AM \& Wallbanks S (1991) Phylogenetic analysis of the genus Lactobacillus and related lactic acid bacteria as determined by reverse transcriptase sequencing of $16 \mathrm{~S}$ rRNA. FEMS Microbiology Letters 77, 5-12.

Colombel JF, Corot A, Neut C \& Romond C (1987) Yoghurt with Bifidobacterium longum reduces erythromycin-induced gastrointestinal effects. Lancet 2, 43.

de Vries W \& Stouthammer AH (1968) Fermentation of glucose, lactose, mannitol and xylose by bifidobacteria. Journal of Bacteriology 96, 472-478.

De Vuyst L \& Vandamme EJ (1994) Antimicrobial potential of lactic acid bacteria. In Bacteriocins of Lactic Acid Bacteria: Microbiology, Genetics and Applications, pp. 91-142 [L De Vuyst and EJ Vandamme, editors]. London: Blackie Academic and Professional.

Djouzi Z \& Andrieux C (1997) Compared effects of three oligosaccharides on metabolism of intestinal microflora in rats inoculated with a human faecal flora. British Journal of Nutrition 78, 313-324.

Ducluzeau R \& Bensaada M (1982) Effet comparé de l'administration unique ou en continu de Saccharomyces boulardii sur l'establissement de diverses souches de Candida dans le tractus digestif de souris garotoxeniques. Annals of Microbiology 133, 149-151.

Dumortier V, Brassart C \& Bouquelet S (1994) Purification and properties of a $\beta$-galactosidase from Bifidobacterium bifidum exhibiting a transgalactosylation reaction. Biotechnology and Applied Biochemistry 19, 341-354.

Elmer GW, Surawicz C \& McFarland L (1996) Biotherapeutic agents: a neglected modality for the treatment and prevention of selected intestinal and vaginal infections. Journal of the American Medical Association 275, 870-876.

Fuller R (1989) Probiotics in man and animals. Journal of Applied Bacteriology 66, 365-378.

Gibson GR, Beatty EB, Wang X \& Cummings JH (1995) Selective stimulation of bifidobacteria in the human colon by oligofructose and inulin. Gastroenterology 108, 975-982. 
Gibson GR, Berry Ottaway P \& Rastall RA (2000) Prebiotics: New Developments in Functional Foods. Oxford: Chandos Publishing Limited.

Gibson GR \& Roberfroid MB (1995) Dietary modulation of the human colonic microbiota: introducing the concept of prebiotics. Journal of Nutrition 125, 1401-1412.

Gibson GR and Roberfroid MB (editors) (1999) Colonic Microbiota, Nutrition and Health. Dordrecht: Kluwer Academic Publishers.

Gibson GR \& Wang X (1994) Regulatory effects of bifidobacteria on the growth of other colonic bacteria. Journal of Applied Bacteriology 77, 412-420.

Gorbach SL, Chang TW \& Goldin B (1987) Successful treatment of relapsing Clostridium difficile colitis with Lactobacillus GG. Lancet 26, 1519.

Halpern GM, Vruwink KG, Van de Water J, Keen CL \& Gershwin ME (1991) Influence of long-term yoghurt consumption in young adults. International Journal of Immunotherapy 7, 205-210.

Hatcher GE \& Lambrecht RS (1993) Augmentation of macrophage phagocytic activity by cell-free extracts of selected lactic acid-producing bacteria. Journal of Dairy Science 76, 2485-2492.

Hayakawa K, Mizutani J, Wada K, Masai T, Yoshihara I \& Mitsuoka T (1990) Effects of soybean oligosaccharides on human faecal flora. Microbial Ecology in Health and Disease 3, 293-303.

Hilton E, Kolakowski P, Smith M \& Singer C (1996) Efficacy of Lactobacillus GG as a diarrhoea preventative. Journal of Travellers Medicine 4, 3-7.

Hitchins AD, Wells P, McDonough FE \& Wong NP (1986) Amelioration of the adverse effect of a gastrointestinal challenge with Salmonella enteriditis on weaning rats by a yoghurt diet. American Journal of Clinical Nutrition 41, 91-100.

Holzapfel WH, Haberer P, Snell J, Schillinger U \& Huis in't Veld JHJ (1998) Overview of gut flora and probiotics. International Journal of Food Microbiology 41, 85-101.

Hotta M, Sato S \& Iwata N (1987) Clinical effects of Bifidobacterium preparations on pediatric intractable diarrhoea. Keio Journal of Medicine 36, 298-314.

Hudault S, Lievin V, Bernet-Camard MF \& Servin A (1997) Antagonistic activity exerted in vitro and in vivo by Lactobacillus casei (strain GG) against Salmonella typhimurium C5 infection. Applied and Environmental Microbiology 63, $513-518$.

Imaizumi K, Nakatsu Y, Sato M, Sedamawati Y \& Sugano M (1991) Effects of xylo-oligosaccharides on blood glucose, serum and liver lipids and short chain fatty acids in diabetic rats. Agricultural and Biological Chemistry 55, 199-205.

Isolauri E, Juntunen M, Rautanen T, Sillanaukee P \& Koivula T (1991) A human Lactobacillus strain (Lactobacillus GG) promotes recovery from acute diarrhoea in children. Pediatrics 88, 90-97.

Isolauri E, Kaila M, Mykkänen H, Ling W-H \& Salminen S (1994) Oral bacteriotherapy for viral gastroenteritis. Digestive Disease Science 39, 2595-2600.

Isolauri E, Majamaa H, Arvola T, Rantala I, Virtanen E \& Arvilommi H (1993) Lactobacillus casei strain GG reverses increased intestinal permeability induced by cow milk in suckling rats. Gastroenterology 105, 1643-1650.

Ito M, Deguchi Y, Miyamori A, Kikuchi H, Matsumoto K, Kobasyashi Y, Yajima T \& Kan T (1990) Effect of administration of galacto-oligosaccharides on the human faecal microflora, stool weight and abdominal sensation. Microbial Ecology in Health and Disease 3, 285-292.

Ito M, Kimura M, Deguchi Y, Miyamori-Watabe A, Yajima T \& Kan T (1993) Effects of transgalactosylated disaccharides on the human intestinal flora and their metabolism. Journal of Nutritional Science and Vitaminology 39, 279-288.

Jack RW, Tagg JR \& Ray B (1995) Bacteriocins of Gram-positive bacteria. Microbiological Reviews 59, 171-200.

Jacobsen CN, Rosenfeldt Nielsen V, Hayford AE, Møller PL, Michaelsen KF, Pærregaard A, Sandström B, Tvede M \& Jakobsen M (1999) Screening of probiotic activities of fortyseven strains of Lactobacillus spp. by in vitro techniques and evaluation of the colonization ability of five selected strains in humans. Applied and Environmental Microbiology 65, 4949-4956.

Jalonen T, Isolauri E, Heyman M, Crain-Denoyelle A-M, Sillanaukee P \& Koivula T (1991) Increased $\beta$-lactoglobulin absorption during rotavirus enteritis in infants: relationship to sugar permeability. Pediatric Research 130, 290-293.

Kabir AMA, Aiba Y, Takagi A, Kamiya S, Miwi T \& Koga Y (1997) Prevention of Helicobacter pylori infection by lactobacilli in a gnotobiotic murine model. Gut 41, 49-55.

Kaila M, Isolauri E, Soppi E, Virtanen E, Laine S \& Arvilommi H (1992) Enhancement of the circulating antibody secreting cell response in human diarrhoea by human Lactobacillus strain. Pediatric Research 32, 141-144.

Kay B, Fuller R, Wilkinson AR, Hall M, McMichael JE \& Cole CB (1990) High levels of staphylococci in the faeces of breastfed babies. Microbial Ecology in Health and Disease 3, 277.

Kebary KMK (1995) Production, partial purification and stability of antimicrobial substances produced by Bifidobacterium bifidum DI. Egyptian Journal of Dairy Science 23, 151-166.

Kennedy MJ \& Volt PA (1985) Ecology of Candida albicans gut colonisation: inhibition of Candida adhesion, colonisation and dissemination from the gastrointestinal tract by bacterial antagonism. Infection and Immunity 49, 654-663.

Klaenhammer TR (1988) Bacteriocins of lactic acid bacteria. Biochemie 70, 337-349.

Kleesen B, Hartman L \& Blaut M (2001) Oligofructose and long chain inulin: influence on the gut microbial ecology of rats associated with a human faecal flora. British Journal of Nutrition 86, 291-300.

Kleesen B, Sykura B, Zunft H-J \& Blaut M (1997) Effects of inulin and lactose on faecal microflora, microbial activity, and bowel habit in elderly constipated persons. American Journal of Clinical Nutrition 65, 1397-1402.

Kohmoto T, Kukui F, Takaku H, Machida Y, Arai M \& Mitsuoka $\mathrm{T}$ (1988) Effect of isomaltooligosaccharides on human faecal flora. Bifidobacteria Microflora 7, 61-69.

Lambert JR \& Hull RR (1996) Upper gastrointestinal tract disease and probiotics. Asian Pacific Journal of Clinical Nutrition 5, 31-35.

Lilley DM \& Stillwell RH (1965) Probiotics, growth promoting factors produced by microorganisms. Science 147, 747-748.

Lindgren SE \& Dobrogosz WJ (1990) Antagonistic activities of lactic acid bacteria in food and feed fermentations. FEMS Microbiology Reviews 87, 149-163.

Luo F, Lambert JR, Hull RR \& Midolo PD (1994) Anti-Helicobacter factors produced by lactic acid bacteria. American Journal of Gastroenterology 89, 1395.

McBain AJ \& Macfarlane GT (1997) Investigations of bifidobacterial ecology and oligosaccharides metabolism in a threestage compound continuous culture system. Scandinavian Journal of Gastroenterology 32, Suppl. 222, 32-40.

McFarland LV, Surawicz CM, Greenberg RN, Elmer GW, Moyer KA, Melcher SA, Bowen KE \& Cox JL (1995) Prevention of $\beta$-lactam-associated diarrhoea by Saccharomyces boulardii compared with placebo. American Journal of Gastroenterology 90, 439-448.

McFarland LV, Surawicz CM, Greenberg RN, Fekerty R, Elmer GW \& Moyer KA (1994) A randomised placebo-controlled trial of Saccharomyces boulardii in combination with standard 
antibiotics for Clostridium difficile disease. Journal of the American Medical Association 271, 1913-1918.

Macfarlane GT \& Cummings JH (1991) The colonic microflora, fermentation and large bowel digestive function. In The Large Intestine: Physiology, Pathophysiology and Disease, pp. 51-92 [SF Phillips, JH Pemberton and RG Shorter, editors]. New York: Raven Press.

Majaama H, Isolauri E, Saxelin M \& Vesikari T (1995) Lactic acid bacteria in the treatment of acute rotavirus gastroenteritis. Journal of Pediatric Gastroenterology and Nutrition 20, $333-339$.

Meghrous J, Euloge P, Junelles AM, Ballongue J \& Petitdemange H (1990) Screening of Bifidobacterium strains for bacteriocin production. Biotechnology Letters 12, 575-580.

Metchnikoff E (1907) The Prolongation of Life. London: Heinemann.

Michetti P, Dorta G, Brassart D \& Vouillamoz D (1995) Lactobacillus acidophilus supernatant as an adjuvant in the therapy of Helicobacter pylori in humans. Gastroenterology 108, 253-258.

Midolo PD, Lambert JR, Hull RR \& Luo F (1995) In vitro inhibition of Helicobacter pylori by organic acids and lactic acid bacteria. Journal of Applied Bacteriology 79, 475-479.

Mikelsaar M, Mändar R \& Sepp E (1998) Lactic acid bacteria in the human microbial ecosystem and its development. In Lactic Acid Bacteria, Microbiology and Functional Aspects, 2nd ed., pp. 279-342 [S Salminen and A von Wright, editors]. New York: Marcel Dekker.

Mitsuoka T (1982) Recent trends in research on intestinal flora. Bifidobacteria Microflora 1, 3-24.

Mitsuoka T (1984) Taxonomy and ecology of bifidobacteria. Bifidobacteria Microflora 3, 11.

Mitsuoka T (1990) Bifidobacteria and their role in human health. Journal of Industrial Microbiology 6, 263-268.

Mitsuoka T, Hayakawa K \& Kimura N (1974) Die faekal flora bei Menshen. II, Mitteilung: die Zuzammensetzung der Bifidobakterien-flora der verschiedenen Altersgruppen. Zentralbl Bakteriolog Parasitenk A226, 469-478.

Modler HW (1994) Bifidogenic factors — sources, metabolism and applications. International Dairy Journal 4, 383-407.

Modler HW, McKellar RC \& Yaguchi M (1990) Bifidobacteria and bifidogenic factors. Canadian Institute of Food Science and Technology 23, 29-41.

Nes IF, Diep DB, Håvarstein LS, Bruberg MB, Eijsink V \& Holo H (1996) Biosynthesis of bacteriocins in lactic acid bacteria. Antonie Leeuwenhook International Journal of General Molecular Microbiology 70, 113-128.

Nomoto K, Nagaoka M, Yokokura T \& Mutai M (1989) Augmentation of resistance of mice to bacterial infection by a polysaccharide-peptidoglycan complex (PSPG) extracted from Lactobacillus casei. Biotherapy 1, 169-177.

Oksanen PJ, Salminen S, Saxelin M, Hamalmein P, Arja IV, Leena MI, Seppo N, Oksanen T, Posti I, Salminen E, Siitonen S, Stuckey H, Topilla A \& Vapaatalo H (1990) Prevention of traveller's diarrhoea by Lactobacillus GG. Annals of Medicine 22, 53-56.

Ouwehand AC (1998) Antimicrobial components from lactic acid bacteria. In Lactic Acid Bacteria, Microbiology and Functional Aspects, 2nd ed., pp. 139-159 [S Salminen and A von Wright, editors]. New York: Marcel Dekker.

Oyarzabal OA \& Conner DE (1995) In vitro fructooligosaccharide utilisation and inhibition of Salmonella spp. by selected bacteria. Poultry Science 74, 1418-1425.

Pant AR, Graham SM, Allen SJ, Harikul S, Sabchareon A, Cuevas L \& Hart CA (1996) Lactobacillus GG and acute diarrhoea in young children in the tropics. Journal of Tropical Pediatrics 42, 162-165.
Parker RB (1974) Probiotics, the other half of the antibiotic story. Animal Nutrition and Health 29, 4-8.

Pelto L, Isolauri E \& Salminen S (1996) Milk hypersensitivity in adults. Nutrition Today S1, 34-35.

Perdigon G, Alvarez S, Nader de Macias ME, Roux ME \& Pesce de Ruiz Holgado A (1990) The oral administration of lactic acid bacteria increase the mucosal intestinal immunity in response to enteropathogens. Journal of Food Protection 53, 404-410.

Rabiu B, Jay AJ, Gibson GR \& Rastall RA (2001) Synthesis and fermentation profiles of novel galacto-oligosaccharides by $\beta$ galactosidases from Bifidobacterium species. Applied and Environmental Microbiology 67, 2526-2526.

Raza S, Graham SM, Allen SJ, Sultana S, Cuevas L \& Hart CA (1995) Lactobacillus GG promotes recovery from acute nonbloody diarrhoea in Pakistan. Pediatrics Infectious Disease Journal 14, 107-111.

Rettger F, Levy MN, Weinstein K \& Weiss JE (1935) Lactobacillus acidophilus and its Therapeutic Application. New Haven, CT: Yale University Press.

Roberfroid MB, Rastall RA \& Gibson GR (1999) Prebiotics. In Colonic Microbiota, Nutrition and Health, pp. 101-125 [GR Gibson and MB Roberfroid, editors]. Dordrecht: Kluwer.

Rogosa M (1974) Bifidobacterium. In Bergey's Manual of Determinative Bacteriology, 8th ed., pp. 669 [RE Buchanan and NE Gibbons, editors]. Baltimore, MD: Williams and Wilkins.

Saavedra JM (1995) Microbes to fight microbes: a not so novel approach to controlling diarrhoeal disease. Journal of Pediatric Gastroenterology and Nutrition 21, 125-129.

Saavedra JM, Bauman NA, Oung I, Perman JA \& Yolken RH (1994) Feeding of Bifidobacterium bifidum and Streptococcus thermophilus to infants in hospital for prevention of diarrhoea and shedding of rotavirus. Lancet 344, 1046-1049.

Sahl H-G \& Bierbaum G (1998) Lantibiotics: biosynthesis and biological activities of uniquely modified peptides from Gram-positive bacteria. Annual Reviews of Microbiology 52, 41-79.

Saito Y, Takano T \& Rowland IR (1992) Effects of soybean oligosaccharides on the human gut microflora in in vitro culture. Microbial Ecology in Health and Disease 5, 105-110.

Salminen S, Ouwehand AC \& Isolauri E (1998) Clinical application of probiotic bacteria. International Dairy Journal 8, $563-572$.

Sanders ME (1993) Effect of consumption of lactic cultures on human health. Advances in Food and Nutrition Research 37, $67-130$.

Scardovi V, Trovatelli LD, Zani G, Gociani F \& Matenzzi D (1971) Deoxyribonucleic acid homology relationships among species of the genus Bifidobacterium. International Journal of Systematic Bacteriology 21, 276-294.

Sepp E, Tamm E, Torm S, Lutsar I, Mikelsaar M \& Salminen S (1995) Impact of a Lactobacillus probiotic on the faecal microflora in children with shigellosis. Microecology and Therapy 23, 74-80.

Shornikova AV, Casas IA, Isolauri E, Mykkänen H \& Vesikari T (1997) Lactobacillus reuteri as a therapeutic agent in acute diarrhoea in young children. Journal of Pediatric Gastroenterology and Nutrition 24, 399-404.

Shortt C (1999) The probiotic century: historical and current perspectives. Trends in Food Science \& Technology 10, 411-417.

Siitonen S, Vapaatalo H, Salminen S, Gordin A, Saxelin M, Wikberg R \& Kirkkola A (1990) Effect of Lactobacillus GG yoghurt in prevention of antibiotic associated diarrhoea. Annals of Medicine 22, 57-59.

Sperti GS (1971) Probiotics. West Point, CT: Avi Publishing.

Surawicz CM, Elmer LW, Speelman P, McFarland LV, Chinn J \& van Belle G (1989) Prevention of antibiotic-associated diarrhoea by Saccharomyces boulardii: a prospective study. Gastroenterology 96, 981-988. 
Sütas Y, Soppi E, Korhonen H, Syväoja E, Saxelin M, Rokka T \& Isolauri E (1996) Suppression of lymphocyte proliferation in vitro by bovine caseins hydrolysed with Lactobacillus GGderived enzymes. Journal of Allergy and Clinical Immunology 98, 216-224.

Talarico TL \& Dobrogosz WJ (1989) Chemical characterisation of an antimicrobial substance produced by Lactobacillus reuteri. Antimicrobiology Agents and Chemotherapy 33, 674-679.

Tanaka R, Takayama H, Morotomi M, Kuroshima T, Ueyama S, Matsumoto K, Kuroda A \& Mutai M (1983) Effects of administration of TOS and Bifidobacterium breve 4006 on the human faecal flora. Bifidobacteria Microflora 2, 17-24.

Tissier H (1906) Recherches sur la flore intestinale des nourissons. University of Paris [G Carre and C Nord, editors]. Paris, France.
Tomoda T, Nakano Y \& Kageyama T (1983) Variation of intestinal Candida of patients with leukaemia and the effect of Lactobacillus administration. Japanese Journal of Medical Mycology 24, 356-358.

Vaughan EE \& Mollet B (1999) Probiotics in the new millennium. Die Nahrung 43, S148-S153.

Wang X \& Gibson GR (1993) Effects of the in vitro fermentation of oligofructose and inulin by bacteria growing in the human large intestine. Journal of Applied Bacteriology 75, 373-380.

Yildrim Z \& Johnson MG (1998) Characterisation and antimicrobial spectrum of Bifidocin B, a bacteriocin produced by Bifidobacterium bifidum NCFB 1454. Journal of Food Protection 61, 47-51.

Yuhara T, Isojima S, Tsuchiya F \& Mitsuoka T (1983) On the intestinal flora of bottle-fed infant. Bifidobacteria Microflora 2, 33-39. 